\title{
Bryozoans, foraminifers, algae, and sedimentological characteristics of an exotic limestone block of the late Viséan Kirchbach Formation, Carnic Alps, Austria
}

\author{
Andrej Ernst, Karl Krainer, Hans-Peter Schönlaub \& Daniel Vachard
}

\begin{abstract}
A late Viséan fossiliferous limestone block from the Kirchbach Formation (Mississippian) in the Carnic Alps (southern Austria) has been studied for its palaeontological and petrographic characteristics. The limestone block contains abundant fossils and is composed of different microfacies including bioclastic floatstone, coral bafflestone, bryozoan bindstone, bryozoan wacke- to grainstone, as well as bioclastic mud- to wackestone. The described fauna of bryozoans and foraminifers identify the age of the block as early Serpukhovian (Tarusian), and indicate deposition in a shallow shelf environment with high to moderate energy levels, moderate to high sedimentation rates and flexible to hard substrates. The limestone block, like the exotic limestone clasts of the carbonate conglomerates of the Kirchbach Formation, were transported into deeper marine environments by gravitational sedimentary processes from a shallow marine carbonate shelf that was developed along the northern margin of the Hochwipfel flysch basin. - Key words: Mississippian, Carnic Alps, Austria, microfacies, Bryozoa, foraminifers, ecology, taxonomy.
\end{abstract}

Ernst, A., Krainer, K., Schönlaub, H.-P. \& Vachard, D. 2021. Bryozoans, foraminifers, algae, and sedimentological characteristics of an exotic limestone block of the late Viséan Kirchbach Formation, Carnic Alps, Austria. Bulletin of Geosciences 96(2), 181-194 (7 figures, 3 tables). Czech Geological Survey, Prague. ISSN 1214-1119. Manuscript received October 12, 2020; accepted in revised form February 8, 2021; published online February 28, 2021; issued April 11, 2021.

Andrej Ernst, Institute for Geology, University of Hamburg, Bundesstr. 55, D-20146 Hamburg, Germany; Andrej. Ernst@uni-hamburg.de • Karl Krainer, Institute of Geology and Paleontology, Innsbruck University, Innrain 52, Innsbruck, A-6020, Austria • Hans-Peter Schönlaub, Kötschach 350, A-9640, Kötschach-Mauthen, Austria • Daniel Vachard, 1 rue des Tilleuls, 59152 Gruson, France \& Université des sciences et technologies de Lille, UMR 8198 du CNRS Evolution, Ecologie et Paléontologie, bâtiment SN5, 59655 Villeneuve d'Ascq cedex, France

The historical background of the Kirchbach Formation (Kirchbach Limestone/Kalk - Schönlaub 1985, Kirchbach Formation - Schönlaub et al. 2015) was summarized by Krainer \& Vachard (2015) and Kabon \& Schönlaub (2019). Schönlaub et al. (2015) defined the Kirchbach Formation as "grayish shale with layers of carbonate nodules and argillaceous nodular limestone and limestone clasts". The nodules are $30-40 \mathrm{~cm}$ large and partly composed of polymict breccia. Limestone clasts contain a diverse fossil assemblage. The thickness of the Kirchbach Formation is $4-8 \mathrm{~m}$. The stratotype is located south of Kirchbacher Wipfel. The carbonate rocks of the Kirchbach Formation are interpreted to be derived from a shallow marine shelf area. The limestone clasts were reworked and transported into deeper marine settings by sediment gravity flows (Krainer \&Vachard 2015, Rodríguez et al. 2018, Kabon \& Schönlaub 2019). The Kirchbach Formation is intercalated in the Hochwipfel Formation and is exposed at several localities NW of the summit of Hochwipfel (2,195 m). In a tributary of Döbernitzgraben at an elevation between 1,500 and $1,580 \mathrm{~m}$, polymict conglomerates within the
Hochwipfel Formation are several tens of metres thick and contain carbonate clasts with diameters up to several decimetres.

Krainer \& Vachard (2015) studied the Kirchbach Formation at an outcrop that is located along the forest road from Wipfelalm to Kirchbacher Wipfel at an elevation of approximately $1,720 \mathrm{~m}$ (Fig. 1). This location is considered as the type locality and type section of the Kirchbach Formation (see Flügel \& Schönlaub 1990, Krainer \& Vachard 2015). At this type locality, the Kirchbach Formation is under- and overlain by shale with intercalated sandstone beds of the Hochwipfel Formation. The Kirchbach Formation is approximately $8 \mathrm{~m}$ thick, starts with shale and intercalated mudstone, and is overlain by micritic limestone $(80 \mathrm{~cm})$ and carbonate conglomerate and breccia (Fig. 2).

The studied limestone block is probably derived from this carbonate conglomerate and breccia. According to Krainer \& Vachard (2015), the micritic limestone bed is composed of bioclastic mudstone with few fossils. The conglomerate and breccia beds are composed of limestone 


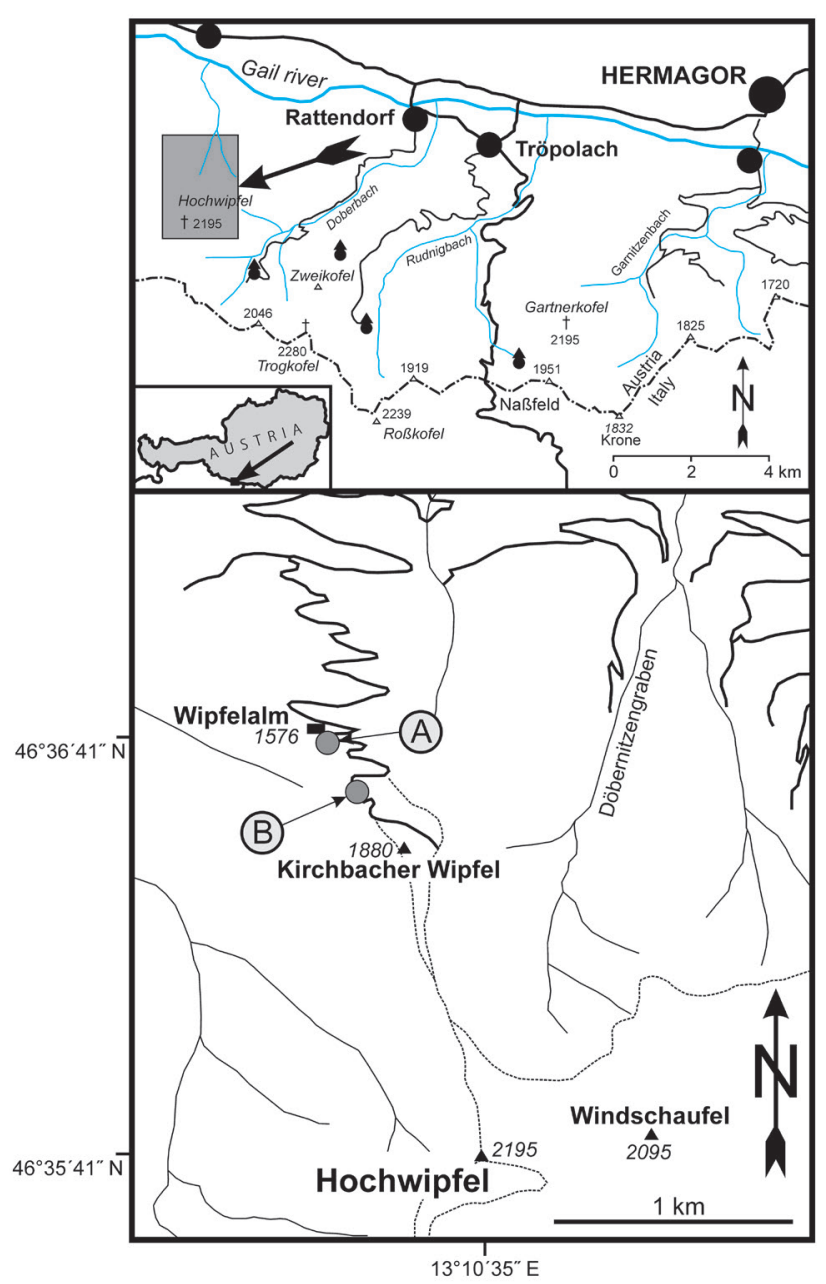

Figure 1. Map of the Hochwipfel area in the Carnic Alps (Austria) showing location of the studied outcrop. Legend: A - location where the studied limestone block was found; B - location of the type section of the Kirchbach Formation.

clasts of different microfacies including bioclastic mudstone, wackestone, packstone, grainstone, rudstone and bindstone. Wackestone, packstone, grainstone and rudstone contain a diverse fossil assemblage. Similar microfacies types were described from these limestone clasts by Flügel \& Schönlaub (1990) and Amler et al. (1991).

The limestone block of the Kirchbach Formation that was discovered by H. Kabon in 2017 (Rodríguez et al. 2018, Kabon \& Schönlaub 2019) contains abundant corals of the genera Lonsdaleia, Syringopora and Axophyllum, crinoids (including several $\mathrm{cm}$ long crinoid stem fragments), bivalves, foraminifers, and calcareous algae (Kabon \& Schönlaub 2019, figs 19, 20).

Rodríguez et al. (2018) reported different microfacies from the limestone block, ranging from bindstone to coral bafflestone and packstone. According to these authors the main building organism is the fasciculate rugose

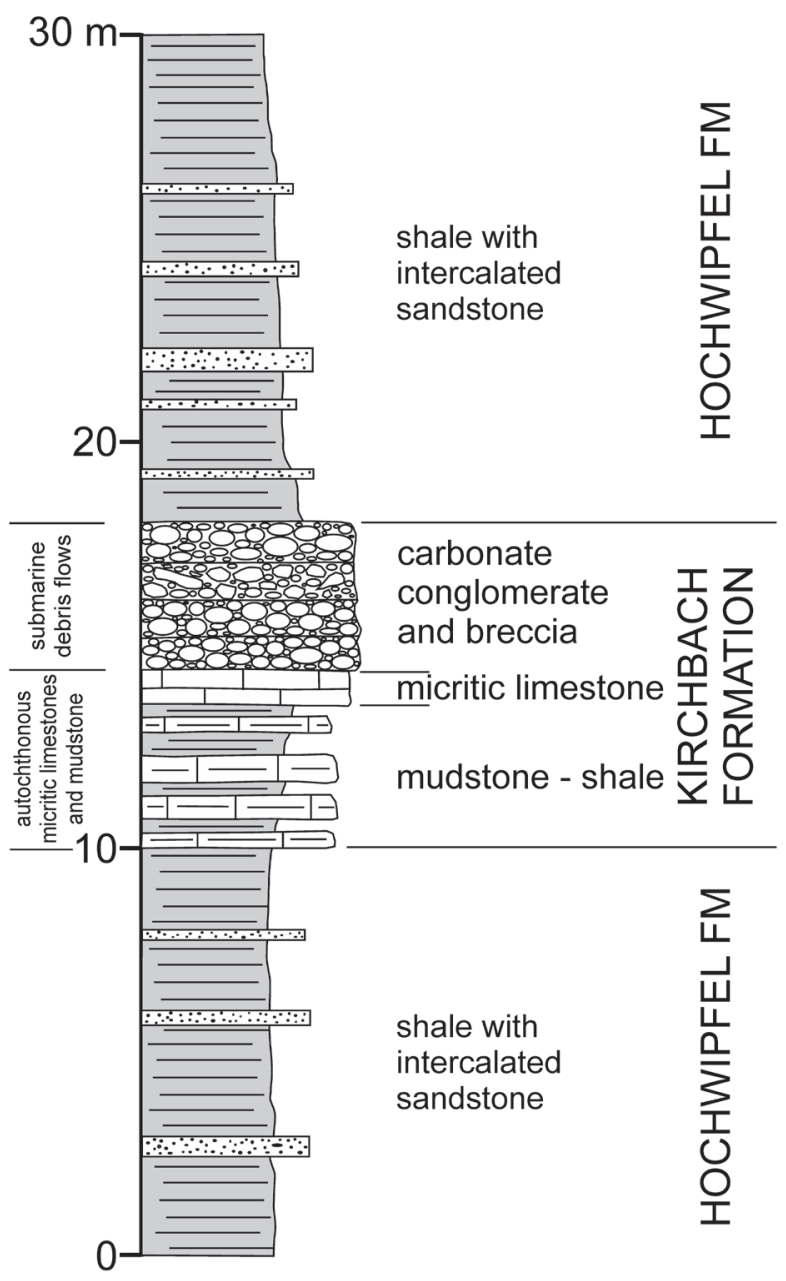

Figure 2. Lithological column of the type section of the Kirchbach Limestone (after Krainer \& Vachard 2015).

coral Lonsdaleia carnica Rodríguez et al. 2018. Other main building organisms are bryozoans, tabulate corals, and calcareous algae. Locally abundant cyanobacteria colonies (Girvanella) are present. Additionally, fragments of crinoids, bivalves, ostracods, brachiopods, trilobites, foraminifers and worm tubes are present. The limestone block is interpreted to be derived from a dominantly lowenergy mound or reef complex which periodically was affected by high turbulence, and was transported into deeper marine environment by gravitational processes. The age of the limestone block is dated as late Viséan to Serpukhovian (Rodríguez et al. 2018).

The present paper aims microfacies analysis of the fossiliferous limestone block, description of bryozoans and foraminifers, discussion of the depositional environment and the age of the Kirchbach Formation as well as palaeogeographic significance of the described fauna. 


\section{Material and methods}

The investigated limestone block was discovered by H. Kabon in 2017 (see above) at an outcrop exposed along a forest road (at "Plunger turn") from Wipfelalm $(1,576 \mathrm{~m})$ to Kirchbacher Wipfel $(1,880 \mathrm{~m})$, at an elevation of $1,650-1,670 \mathrm{~m}$ in the Carnic Alps, Carinthia (Southern Austria). During the road construction the slope was cut and the loose block was used to stabilize the face of the road. It probably is derived from the outcrops of the type locality which is located farther south at a distance of approximately $120 \mathrm{~m}$ at an elevation of approximately 1,720 m (Fig. 1).

From the discovered block, 31 thin sections were prepared for microfacies analysis and palaeontological studies (housed at the Institute of Geology, University of Innsbruck, abbreviations KK and KBK). Bryozoans were investigated in thin sections using a binocular microscope in transmitted light.

\section{Lithology}

The limestone block originally occurred either in shale/ siltstone with intercalated sandstone of the Hochwipfel Formation (olistolith), or, more probably from the carbonate conglomerate/breccia of the type locality (section) of the Kirchbach Limestone (Kirchbach Formation).

The block is a medium grey to dark grey, fossiliferous limestone measuring approximately $65 \times 40 \times 20 \mathrm{~cm}$ (weight is approximately $60 \mathrm{~kg}$ ). This block was split into a larger and a smaller block (see Rodríguez et al. 2018, fig. 2; Kabon \& Schönlaub 2019, fig. 29).

\section{Description of microfacies}

Within the studied limestone block different microfacies types were recognized: bioclastic floatstone/rudstone, coral bafflestone, bryozoan bindstone, and bryozoan wackestone to grainstone. Smaller limestone clasts are composed of bioclastic mudstone to wackestone.

Bioclastic floatstone to rudstone. - This microfacies is composed of larger fossil fragments such as shells and shell fragments of brachiopods, bryozoans and echinoderms (crinoids, up to $1 \mathrm{~cm}$ in diameter) and smaller fossils including echinoderms (crinoids), ostracods, palechinid radioles, and rare foraminifers and calcareous algae (Fig. 3A). Locally, bryozoans are encrusting brachiopod shells. Rarely, Eotuberitina and Tuberitina encrust skeletal grains. Bioclastic floatstone locally contains pelmicritic matrix and rudstone is cemented by sparry calcite.
Coral bafflestone. - Locally, small colonies of the colonial rugose coral Lonsdaleia carnica are present that seem to have acted as sediment bafflers (Fig. 3B). The corals are embedded in micritic and pelmicritic matrix that contains few smaller fossils including echinoderm fragments, brachiopods, bryozoans, ostracods, smaller foraminifers and rare calcareous algae. The coral Lonsdaleia carnica is a new species that recently was described from the block by Rodríguez et al. (2018). Additionally, Rodríguez et al. (2018) observed tabulate corals, cyanobacteria (Girvanella), trilobites, and worm tubes.

Bryozoan bindstone. - Locally, up to several $\mathrm{cm}$ large bryozoan colonies of Glyptopora michelinia (Prout, 1860) are present that are attached on the sediment, locally encrusting fossil fragments, particularly echinoderm fragments and brachiopod shells (Figs 3C; 4E, F). The micritic matrix contains echinoderm fragments, brachiopods, ostracods and rare foraminifers.

Bryozoan wackestone to grainstone. - This microfacies contains abundant bryozoan fragments, subordinately echinoderm fragments, shell debris derived from brachiopods, foraminifers, ostracods and rare gastropods that are either embedded in micritic matrix or locally are cemented by sparry calcite (Fig. 3D, E).

Bioclastic mudstone to wackestone. - microfacies of a smaller limestone clast. This microfacies is bioturbated and displays a flasery texture. Small recrystallized skeletons, few ostracods, echinoderm fragments and thin bivalve shells are embedded in silty micrite. Locally, abundant small diagenetic pyrite grains are present (Fig. 3F).

\section{Systematic palaeontology}

Phylum Bryozoa Ehrenberg, 1831

Class Stenolaemata Borg, 1926

Superorder Palaeostomata Ma et al., 2014

Order Cystoporata Astrova, 1964

Suborder Fistuliporina Astrova, 1964

Family Fistuliporidae Ulrich, 1882

\section{Genus Fistulipora M'Coy, 1849}

Type species. - Fistulipora minor M'Coy, 1849. Carboniferous; England.

Diagnosis. - Massive, encrusting or ramose colonies. Cylindrical autozooecia with thin walls and complete diaphragms. Apertures rounded, possessing horse-shoe shaped lunaria. Autozooecia separated by the extrazooidal vesicular skeleton. 
Remarks. - Fistulipora M'Coy, 1849 differs from Eridopora Ulrich, 1882 in having rounded, horseshoe-shaped lunaria instead of triangular ones. Furthermore, Eridopora develops persistently encrusting colonies, whereas Fistulipora may also develop massive and branched colonies. Fistulipora differs from Dybowskiella Waagen \& Wentzel, 1886 in the shape of lunaria, whose ends do not inflect autozooecial chambers.

Occurrence. - Ordovician to Permian; worldwide.

\section{Fistulipora incrustans (Phillips, 1836)}

Figure 4A, B; Table 1

See full synonymy of Fistulipora incrustans (Phillips, 1836) in Bancroft \& Wyse Jackson (1995, p. 131-133). An additional record of this species was published by Ernst \& Rodríguez (2013, p. 178, figs 3e, 3f, 4a, 4b).

Material. - Two colonies KBK-OC-1 and KBK-2A-3.

Description. - Encrusting colony, $0.66-1.83 \mathrm{~mm}$ thick. Autozooecia growing from thin epitheca, bending in the early exozone to the colony surface. Basal diaphragms rare. Autozooecial apertures circular to oval. Lunaria welldeveloped, rounded; ends of lunaria not indenting into autozooecia. Vesicles small to large, separating autozooecia in 1-2 rows, 10-14 surrounding each autozooecia aperture, with flat roofs, polygonal in tangential section. Autozooecial walls granular prismatic, $0.010-0.015 \mathrm{~mm}$ thick. Maculae not observed.

Remarks. - Two species from the Mississippian of Russia are similar to Fistulipora incrustans (Phillips, 1836): F. parvilabrum Schulga-Nesterenko, 1955 and F. steshevensis Schulga-Nesterenko, 1955. They have smaller and fewer vesicles surrounding autozooecial aperture (7-8 in F. parvilabrum and 8-9 in F. steshevensis vs. 10-14 in F. incrustans).
Occurrence. - Carboniferous, Mississippian, Viséan (Asbian-Brigantian); England, Scotland, Ireland. Carboniferous, Mississippian, Viséan (Asbian-Brigantian); El Collado, south-western Spain. Kirchbach Formation, Mississippian; Carnic Alps, Austria.

\section{Genus Eridopora Ulrich, 1882}

Type species. - Eridopora macrostoma Ulrich, 1882, by original designation. Lower Carboniferous; North America.

Diagnosis. - Thin encrusting colonies. Oval apertures with strongly developed lunaria of distinct triangular shape. Cylindrical autozooecia with thin walls and complete diaphragms.

Vesicular skeleton consists of angular vesicles.

Remarks. - Eridopora Ulrich, 1882 differs from Fistulipora $\mathrm{M}^{\prime} \mathrm{Coy}, 1849$ in having large triangular lunaria instead of horse-shoe shaped ones, and predominantly encrusting colonies.

Occurrence. - Devonian to Permian; worldwide.

\section{Eridopora macrostoma Ulrich, 1882}

Figure 4C, D; Table 2

1882 Eridopora macrostoma Ulrich; p. 137, pl. 6, figs 1, 2a.

1884 Eridopora macrostoma Ulrich, 1882. - Ulrich, pl. 3, fig. 8.

1895 Eridopora macrostoma Ulrich, 1882. - Simpson, p. 561, fig. 128.

1953 Eridopora macrostoma Ulrich, 1882. - Bassler, p. g85, figs 50, 3a-c.

1953 Eridopora aff. macrostoma Ulrich, 1882.- Nekhoroshev, p. 55 , pl. 23, fig. 1a, b.

1963 Eridopora macrostoma Ulrich, 1882. - Perry \& Horowitz, p. 24, pl. 4, figs 1, 2.

\begin{tabular}{lcccccc}
\hline & $\mathrm{N}$ & $\mathrm{X}$ & $\mathrm{SD}$ & $\mathrm{CV}$ & $\mathrm{MIN}$ & $\mathrm{MAX}$ \\
\hline Aperture width, mm & 20 & 0.32 & 0.045 & 14.19 & 0.26 & 0.40 \\
Aperture spacing, mm & 20 & 0.48 & 0.075 & 15.69 & 0.30 & 0.60 \\
Vesicle diameter, mm & 20 & 0.10 & 0.034 & 33.63 & 0.06 & 0.20 \\
Vesicles per aperture & 8 & 11.8 & 1.581 & 13.46 & 10.0 & 14.0 \\
\hline
\end{tabular}

\begin{tabular}{lcccccc}
\hline & $\mathrm{N}$ & $\mathrm{X}$ & $\mathrm{SD}$ & $\mathrm{CV}$ & $\mathrm{MIN}$ & $\mathrm{MAX}$ \\
\hline Aperture width, mm & 10 & 0.36 & 0.047 & 13.19 & 0.28 & 0.42 \\
Aperture spacing, mm & 10 & 0.46 & 0.052 & 11.40 & 0.38 & 0.55 \\
Vesicle diameter, mm & 10 & 0.12 & 0.021 & 17.19 & 0.10 & 0.16 \\
\hline
\end{tabular}

Table 1. Descriptive statistics of Fistulipora incrustans (Phillips, 1836). Abbreviations: $\mathrm{N}$ - number of measurements; $\mathrm{X}$ - mean; SD - sample standard deviation; $\mathrm{CV}$ - coefficient of variation; MIN - minimal value; MAX maximal value.

Table 2. Descriptive statistics of Eridopora macrostoma Ulrich, 1882. Abbreviations as for Table 1. 

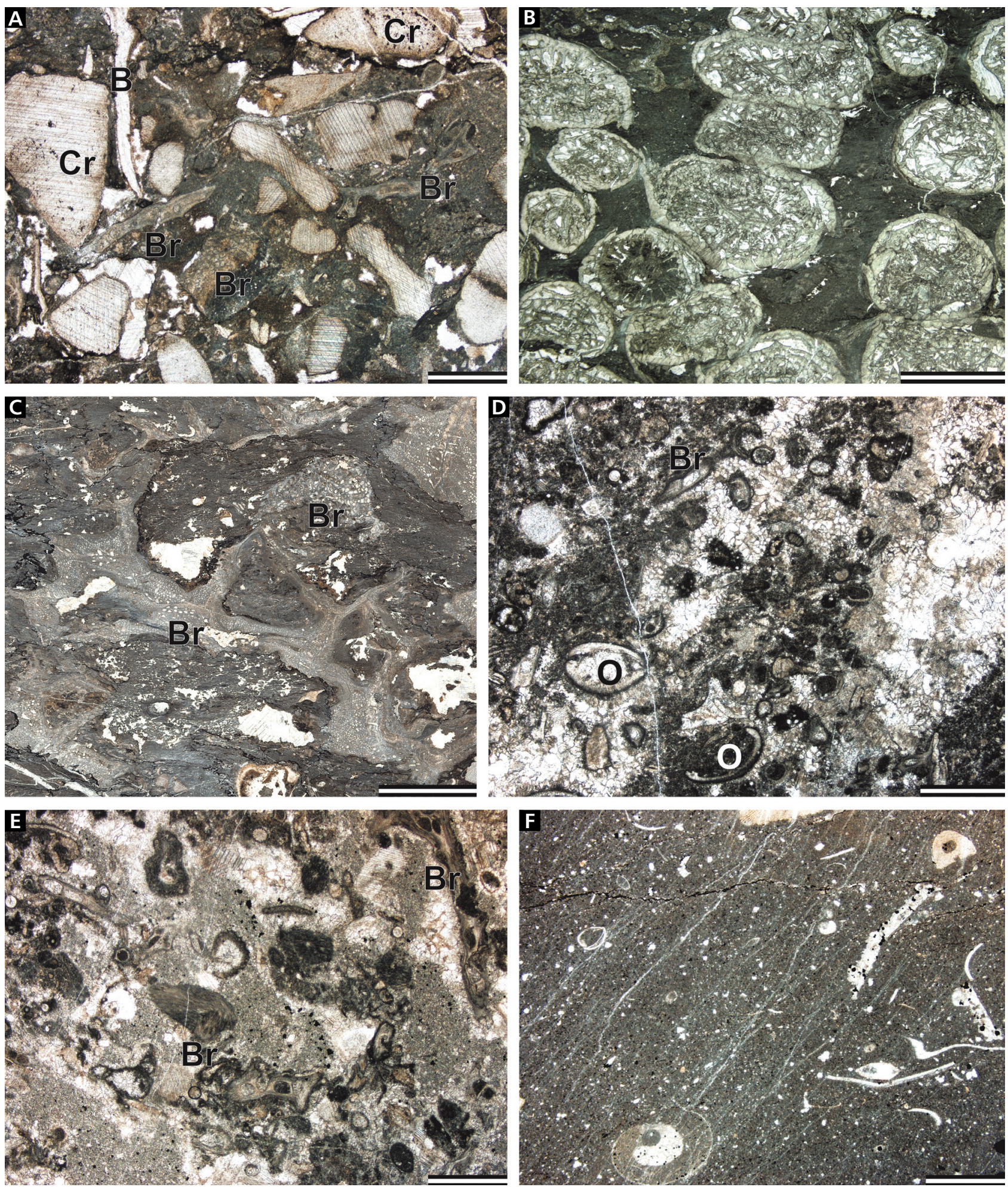

Figure 3. Microfacies types from the studied block. • A - KK-08-2, bioclastic rudstone. • B - KK-05-2, coral bafflestone. $\bullet$ C - KK-03b, bryozoan bindstone. $\bullet$ D - KK-04-20, bryozoan wackestone. $\bullet$ E - KK-04a-24, bryozoan grainstone. $\bullet$ F - KBK-c-1, bioclastic mudstone to wackestone. Scale bars: $5 \mathrm{~mm}$ (B, C), $1 \mathrm{~mm}$ (A, D-F). Abbreviations: B - brachiopod shell; $\mathrm{Br}$ - bryozoan; $\mathrm{Cr}$ - crinoid; $\mathrm{O}$ - ostracod shell.

1972 Eridopora macrostoma Ulrich, 1882. - McKinney, p. 29, pl. 5, figs 6, 7; pl. 6, figs 1, 2, 5 .
1983 Eridopora macrostoma Ulrich, 1882. - Utgaard, p. 393, fig. 181, la-d. 

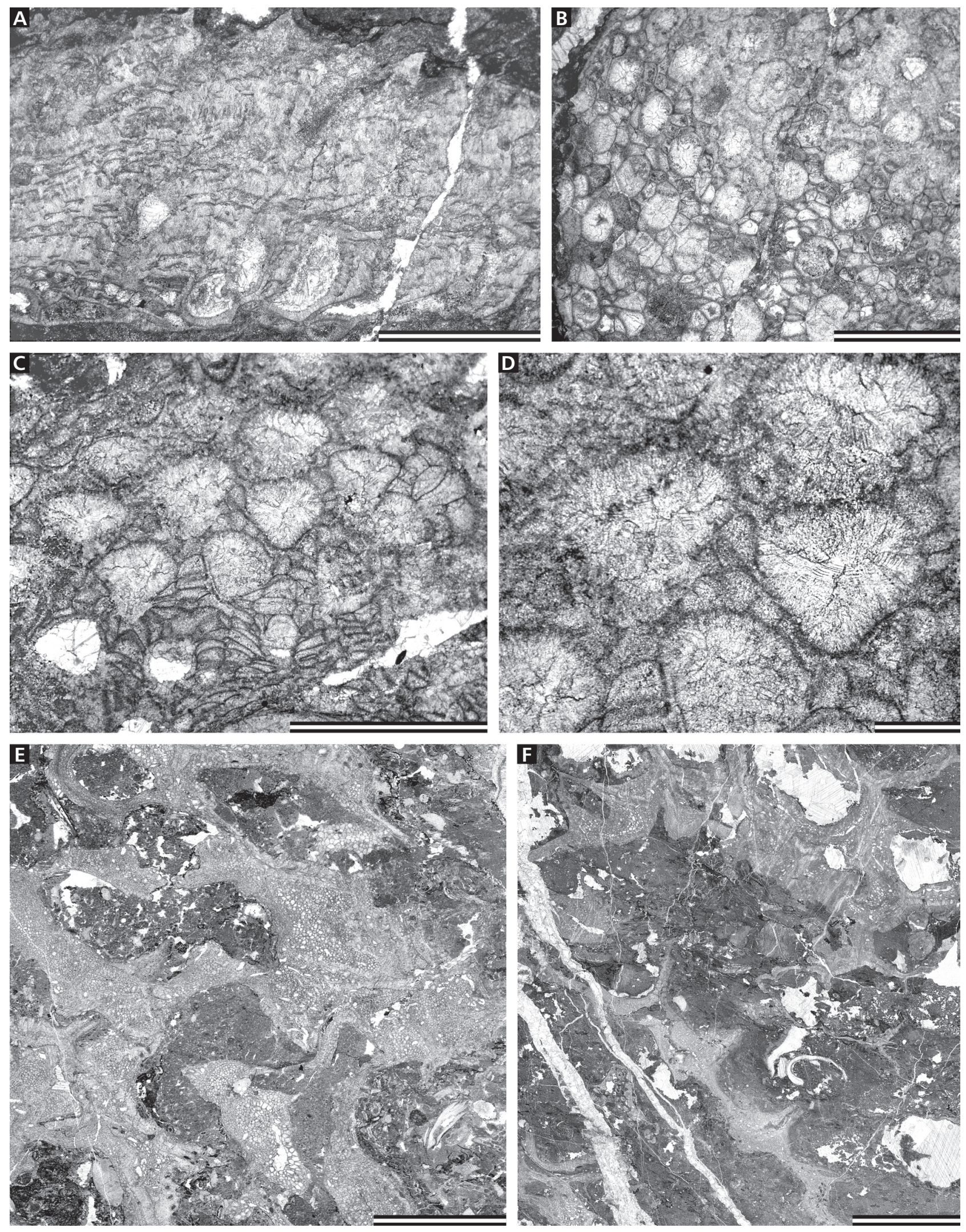

Figure 4. Bryozoans from the studied block. • A, B - Fistulipora incrustans (Phillips, 1836), KBK-OC-1, longitudinal (A), and tangential section (B). • C, D - Eridopora macrostoma Ulrich, 1882, KBK-2A-3, tangential section. • E, F - Glyptopora michelinia (Prout, 1860), KBK-2A-4 (E), KBK-03c (F), thin sections through honeycomb-shaped colonies. Scale bars: $5 \mathrm{~mm}$ (E, F), $1 \mathrm{~mm}(\mathrm{~A}-\mathrm{D}), 0.2 \mathrm{~mm}$ (D). 

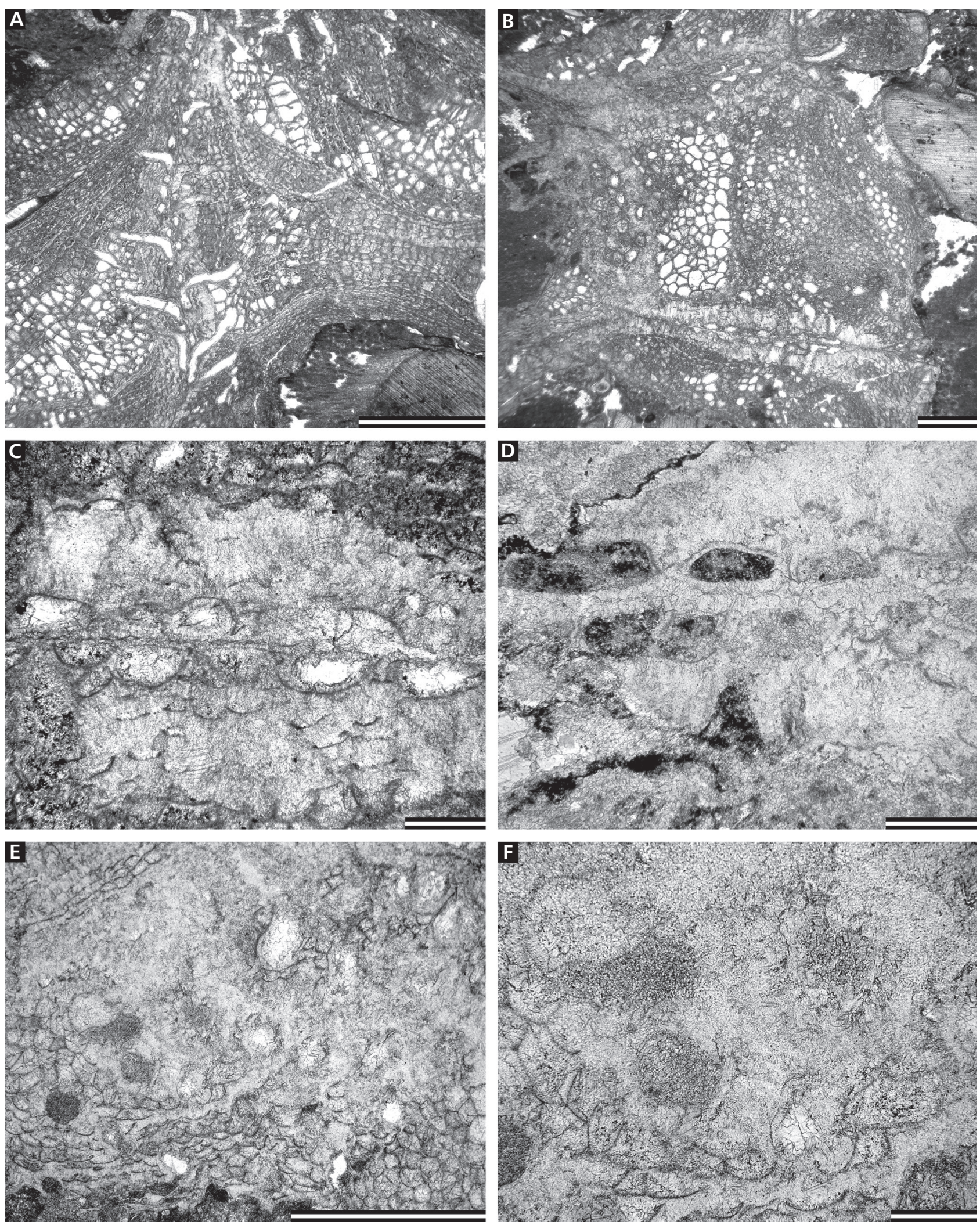

Figure 5. Bryozoans from the studied block. - A-F - Glyptopora michelinia (Prout, 1860); A, B - KBK-2A-4, longitudinal (A) and tangential (B) sections through honeycomb-shaped subcolony; C - KBK-0D-1, transverse section through lobe showing autozooecia, vesicles and mesotheca with rods; D - KBK-2A-4, transverse section through lobe showing autozooecia and mesotheca with rods; E, F - KBK-2A-4, tangential section showing autozooecial apertures and vesicles. Scale bars: $1 \mathrm{~mm}(\mathrm{~A}, \mathrm{~B}, \mathrm{E}), 0.2 \mathrm{~mm}(\mathrm{C}, \mathrm{D}, \mathrm{F})$. 
1986 Eridopora macrostoma Ulrich, 1882. - Bancroft, p. 24, figs $1.1-4,2.1-8,10-13$.

Material. - Single colony KBK-2A-3.

Description. - Thin encrusting colony. Autozooecia growing from thin epitheca, bending in the early exozone to the colony surface. Basal diaphragms rare to absent. Autozooecial apertures circular to oval. Lunaria welldeveloped, triangular; ends of lunaria not indenting autozooecia. Vesicles small to large, separating autozooecia in 1 row, 12-14 surrounding each autozooecia aperture, with rounded roofs, polygonal in tangential section. Autozooecial walls granular prismatic, $0.010-0.015 \mathrm{~mm}$ thick. Maculae not observed.

Remarks. - Eridopora macrostoma Ulrich, 1882 differs from E. definitiva Gorjunova, 1988 from the Mississippian of Mongolia in larger autozooecial apertures (aperture width $0.28-0.42 \mathrm{~mm} v s .0 .18-0.26 \mathrm{~mm}$ in $E$. definitiva). Eridopora macrostoma differs from E. singula Morozova \& Weis in Morozova et al., 2006 from the Mississippian (Tournaisian) of Poland in larger autozooecial apertures (aperture width $0.28-0.42 \mathrm{~mm}$ vs. $0.22-0.25 \mathrm{~mm}$ in E. singular).

Occurrence. - Carboniferous, Mississippian (ViséanSerpukhovian); USA, England, Austria, Kazakhstan.

Suborder Hexagonellina Morozova, 1970

Family Hexagonellidae Crockford, 1947

\section{Genus Glyptopora Ulrich, 1884}

Type species. - Coscinium plumosum Prout, 1860. Mississippian, Carboniferous; USA (Illinois).

Diagnosis. - Colony consisting of erect bifoliate lobes which may join to form inverted polygonal subcolonies in a honeycomb-shaped structure. Mesotheca with a dark and thin middle layer and two light and thick outer layers, containing median rods and longitudinal ridges parallel to growth direction. Autozooecia recumbent on the mesotheca or epitheca for a long distance, then bending upwards abruptly or gently, intersecting the surface almost perpendicularly. Hemisepta absent. Thin, complete diaphragms in autozooecia, common to abundant. Autozooecial apertures circular to oval. Lunaria often developed. Autozooecia separated by vesicular skeleton. Vesicular skeleton covered in outer parts by calcite material. Microacanthostyles in outer layer of the calcite material. Maculae depressed, long, narrow, consisting of stereom (modified after Utgaard 1983).

Remarks. - Glyptopora differs from Evactinopora Meek $\&$ Worthen, 1865 in absence of hemisepta, and from Prismopora Hall, 1883 in presence of median tubuli in mesotheca and absence of hemisepta.

Occurrence. - Carboniferous-Permian; North America, Europe, Australia.

Glyptopora michelinia (Prout, 1860)

Figures 3C; 4E, F; 5A-F; Table 3

1860 Coscinium michelinia Prout; p. 573.

1866 Coscinium michelinia Prout, 1860. - Prout, p. 414, pl. 22, figs 4, 4o.

1890 Glyptopora michelinia (Prout, 1860). - Ulrich, pp. 515, 516, pl. 78, figs 8-8b.

2013 Glyptopora michelinia (Prout, 1860). - Ernst \& Rodríguez, p. 179, figs 4c-e, 5a-f, 6a-d.

2017 Glyptopora michelinia (Prout, 1860). - Ernst \& Vachard, p. 21, figs $4 \mathrm{a}-\mathrm{f}$.

Material. - KBK-0C-1, KBK-0D-1, KBK-0E-1, KBK0Fa, KBK-2A-(1-4), KK-03(a-c), KK-07b.

Description. - Colony initially encrusting, producing a series of erect bifoliate lobes. Lobes usually trifurcating radially and fused together forming a honeycomb-shaped structure. Lobes diverging radially from the central axis at angles of $100-145^{\circ}$. Bifoliate lobes $0.6-1.0 \mathrm{~mm}$ thick. Mesotheca with a dark and thin middle layer and two light and thick outer layers, $0.02-0.05 \mathrm{~mm}$ thick, containing abundant median tubuli. Median tubuli consisting of hyaline calcite, rounded in transverse section, $0.010-0.015$ $\mathrm{mm}$ in diameter, developing short and densely spaced lateral projections. Autozooecia recumbent on the mesotheca or epitheca for a relatively long distance, then bending upwards abruptly, intersecting the surface almost perpendicularly. Thin, complete diaphragms in autozoo-

Figure 6. Foraminifers from the studied block. • A - Anatolipora carbonica Konishi, 1956, KK-06-2, typical longitudinal section. $\bullet$ B, C - Fasciella kizilia Ivanova, 1973; B - KK-04a-11, transverse section; C - KK-04a-11a, oblique transverse section. • D - Tuberitina sp., KK-04-7, axial section. • E - Paraarchaediscus grandiculus (Shlykova, 1951), KBK-0-1, transverse section. • F - Paraarchaediscus stilus (Grozdilova \& Lebedeva in Grozdilova, 1953), KK-04a-22, subaxial section. - G - Earlandia minor (Rauzer-Chernousova, 1948a), KK-03-1, subaxial section. • $\mathrm{H}$ - Monotaxinoides gracilis (Dain in Reitlinger, 1956), KK-04a-1, axial section. • I - Hemidiscopsis cf. muradymicus (Kulagina in Kulagina et al., 1992), KK-04a-3, subaxial section. - J, R - ?Mstinia minima Brazhnikova in Brazhnikova et al., 1956; J - KK-04a-21, transverse section; 

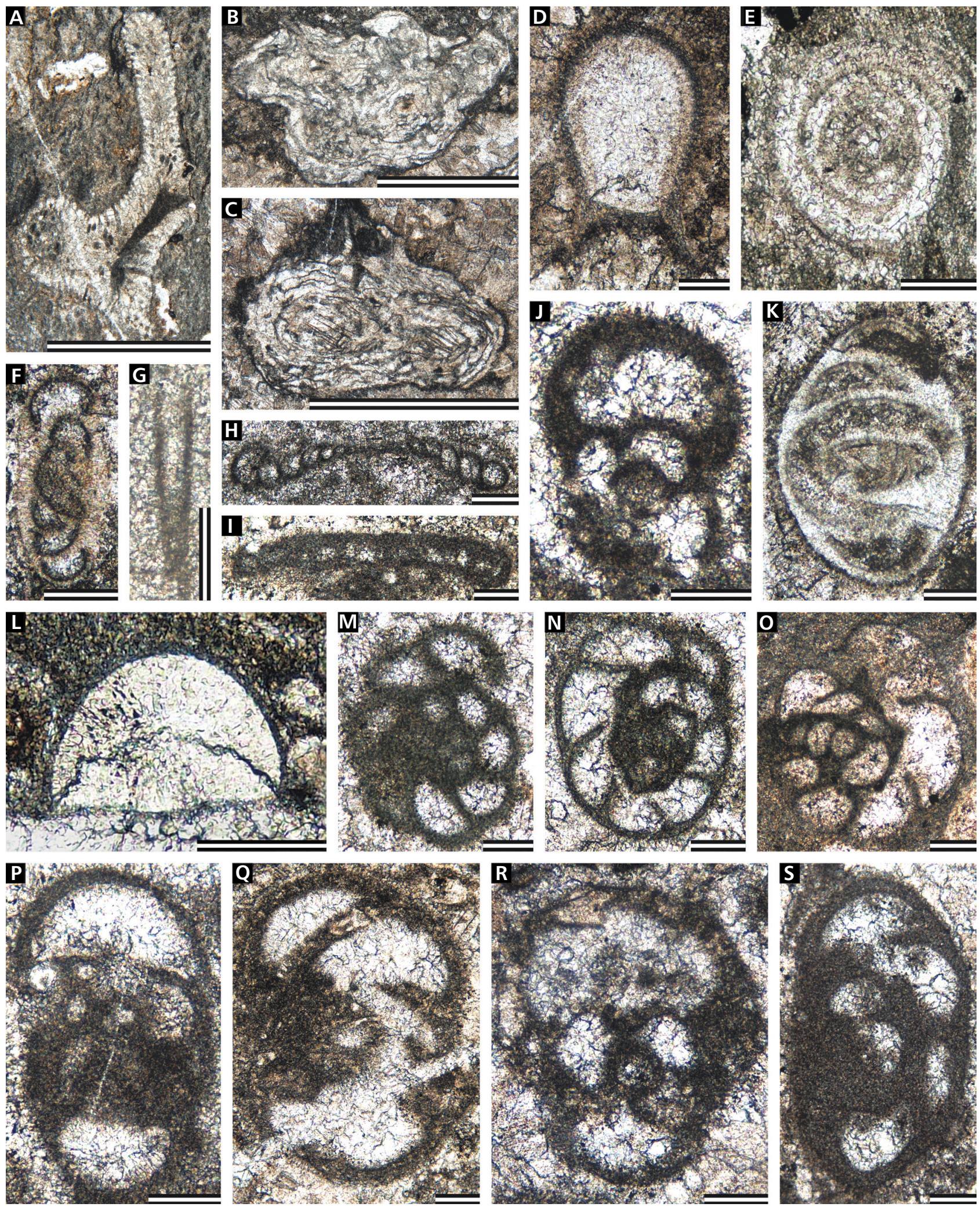

R- KK-04-17, transverse section. $・ \mathrm{~K}$ - Archaediscus karreri (Brady, 1873), KK-04-2, subaxial section. • L-Eotuberitina sp., KBK-0-3, axial section. • M - Planoendothyra sp. 1, KK-04a-17, subtransverse section. $・ \mathrm{~N}-$ Endothyra bowmani Phillips, 1846 sensu Brady, 1876 emend. China, 1965 , KK-04a-18a, transverse section. • O - ?Semiendothyra cf. penningtonensis (Rich, 1980), KK-05-1, transverse section. • P - Planoendothyra sp. 2 , KK-04a-18, subaxial section. - Q - Planoendothyra sp. 3, KK-04a-5a, subtransverse section. - S - Planoendothyra sp. 4, KK-04-18, subtransverse section. Scale bars: $1 \mathrm{~mm}(\mathrm{~A}-\mathrm{C}), 0.1 \mathrm{~mm}(\mathrm{D}-\mathrm{S})$. 


\begin{tabular}{lcccccc}
\hline & $\mathrm{N}$ & $\mathrm{X}$ & $\mathrm{SD}$ & $\mathrm{CV}$ & $\mathrm{MIN}$ & $\mathrm{MAX}$ \\
\hline Aperture width, mm & 10 & 0.14 & 0.015 & 10.91 & 0.11 & 0.16 \\
Aperture spacing, mm & 10 & 0.38 & 0.041 & 10.95 & 0.31 & 0.46 \\
Vesicle diameter, mm & 10 & 0.08 & 0.022 & 26.30 & 0.07 & 0.12 \\
Vesicles per aperture & 6 & 8.7 & 0.816 & 9.42 & 8.0 & 10.0 \\
\hline
\end{tabular}

Table 3. Descriptive statistics of Glyptopora michelinia (Prout, 1860). Abbreviations as for Table 1. ecia rare. Autozooecial apertures circular to oval. Lunaria developed, horseshoe-shaped to triangular. Vesicular skeleton well developed, covered in outer parts by calcite material. Vesicles moderately large, polygonal in tangential section, with rounded roofs, arranged in 1-3 rows between autozooecia, 7-10 surrounding each autozooecial aperture. Thin layer of extrazooecial material developed on the colony surface, containing tubules. Longitudinal depressed maculae lacking autozooecia apparently developed near bases of erect lobes along the axis of their fusion. Depressed maculae lacking autozooecia places between of fusion present, rounded, $0.55-0.88 \mathrm{~mm}$ in diameter.

Remarks. - Glyptopora michelinia (Prout, 1860) differs from G. plumosa (Prout, 1860) in the mode of lobe diverging. Whereas Glyptopora michelinia produced cups by lobes attached to a substrate, the lobes in G. plumosa arose from a common base and bifurcated and trifurcated to produce cups. Furthermore, maculae are less commonly developed in Glyptopora michelinia than in G. plumosa. Glyptopora michelinia possesses few diaphragms in contrast to G. plumosa, and has slightly smaller autozooecial apertures $(0.11-0.16 \mathrm{~mm} v s .0 .15-0.20 \mathrm{~mm}$ in G. plumosa).

Occurrence. - Mississippian, Viséan; USA Illinois, Missouri, Virginia. Mississippian, uppermost Viséan (Brigantian); Caleras Bajas and Antolín sections, south-western Spain. Mississippian, uppermost Viséan (Venevian) to lowermost Serpukhovian (Tarusian) of Tourière and slope of Bataille, southern France. Kirchbach Formation, Mississippian; Carnic Alps, Austria.

\section{Foraminifers and calcareous algae}

The studied block bears rich assemblage of foraminifers and calcareous algae which encompasses the following taxa: the green alga Anatolipora carbonica Konishi, 1956, the incertae sedis alga Fasciella kizilia Ivanova, 1973, the calcitarcha Eotuberitina and Tuberitina, and the foraminifers: Paraarchaediscus grandiculus (Shlykova, 1951), P. stilus (Grozdilova \& Lebedeva in Grozdilova, 1953), Archaediscus karreri (Brady, 1873), Monotaxinoides gracilis (Dain in Reitlinger, 1956), Hemidiscopsis cf. muradymicus (Kulagina in Kulagina et al., 1992), Earlandia minor (Rauzer-Chernousova, 1948a), ?Mstinia minima Brazhnikova in Brazhnikova et al., 1956, Endothyra bowmani Phillips, 1846 sensu Brady, 1876 emend. China, 1965, Planoendothyra spp., ?Semiendothyra cf. penningtonensis (Rich, 1980), ?Eostaffella ex gr. prisca Rauzer-Chernousova, 1948b, Consobrinellopsis sp., Tetrataxis palaeotrochus (Ehrenberg, 1854), T. angusta Vissarionova, 1948, Quasilituotuba sp., ?Warnantella sp. (Figs 6, 7).

All these taxa are present in the Viséan/Serpukhovian boundary interval, and, paradoxically they are more similar to the early Serpukhovian association recently found in the Nötsch Fm. (Vachard et al. 2018) instead of previous descriptions of the Kirchbach Formation, which were late Viséan in age (Amler et al. 1991, Krainer \& Vachard 2015), and generally from the biozone MFZ14 of Poty et al. (2006). The Steshevian assemblage described in the Nötsch Formation by Vachard et al. (2018) shows more evolved taxa of Miliolata and Endothyroidea and, in consequence, the assemblage described in this paper could be Tarusian (i.e. earliest Serpukhovian) in age, and belong to the upper MFZ15 biozone.

\section{Discussion}

The Kirchbach Formation represents autochthonous mudstone (bioclastic mudstone to wackestone) and conglomerate/breccia of sediment gravity flows that contain limestone clasts derived from a shallow marine

Figure 7. Foraminifers from the studied block. • A - Endothyra bowmani Phillips, 1846 sensu Brady, 1876 emend. China, 1965, KK-04-19, transverse section. • B - Planoendothyra sp. 5 KK-04-16, oblique transverse section. • C?, G, I, J - ?Eostaffella ex. gr. prisca Rauzer-Chernousova, 1948b; C - KK-04-8, transverse section; G - KK-04a-6, axial section; I - KK-04a-4, axial section; J - KK-04a-13, axial section. • D-F - Planoendothyra sp.; D - KK-04-15, oblique axial section; E - KK-04a-12, oblique axial section; F - KK-04a-5a, oblique transverse section. • H - Planoendothyra sp. 2, KK-04a-7, axial section. • K - Consobrinellopsis sp., KK-04a-1, subaxial section. • L - Tetrataxis palaeotrochus (Ehrenberg, 1854), KBK-04-8, subaxial section. $\cdot \mathrm{M}$ - Tetrataxis angusta Vissarionova, 1948, KBK-01-1, subaxial section. • N - Quasilituotuba sp., KBK-04-1, subtransverse section. • $\mathrm{O}, \mathrm{P}$ - ?Warnantella sp.; O - KBK-04-3, subtransverse section; P-KBK-04-7, oblique section. Scale bars: 1 mm (L), 0.1 mm (A-K, N-P). 

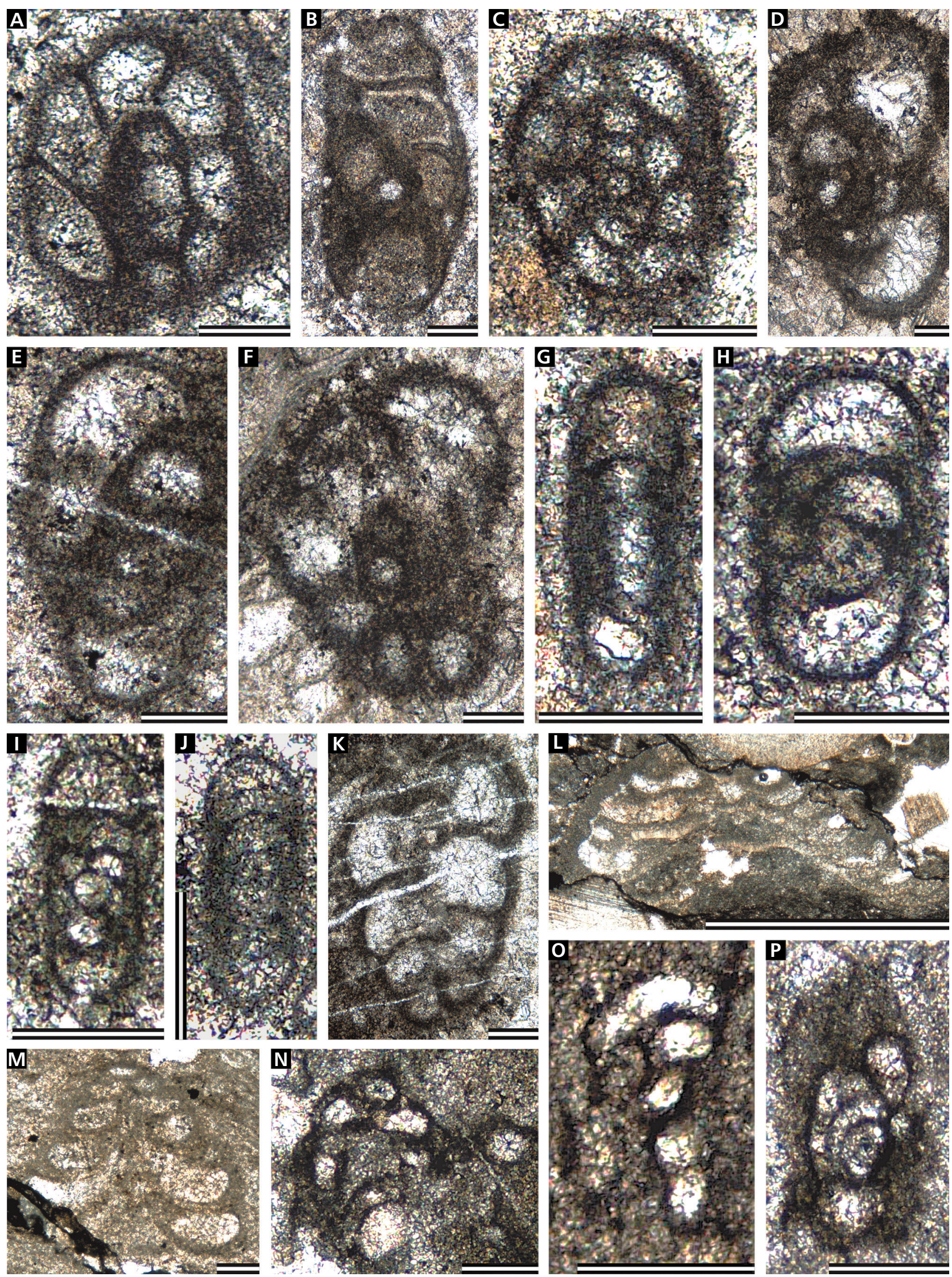
shelf environment. This formation is intercalated in the early Viséan to Bashkirian Hochwipfel Formation that is composed of synorogenic deep marine siliciclastic sediments deposited in a flysch basin that formed during an extensional rifting phase in the foreland of the Noric terrane. The Hochwipfel flysch basin was closed during the Bashkirian (Variscan orogeny) (see discussion in Krainer \& Vachard 2015).

Microfacies and fossils of the limestone clasts that are present in the conglomerates and breccias of the Kirchbach Formation indicate that they are derived from a shallow marine carbonate shelf with different shallow water environments. This carbonate shelf was developed along the northern margin of the Hochwipfel flysch basin. The limestone clasts were transported into deeper marine environments by sediment gravity flows (submarine debris flows) (Flügel \& Schönlaub 1990, Krainer \& Vachard 2015, Rodríguez et al. 2018, Kabon \& Schönlaub 2019).

Foraminifers of these limestone clasts indicate a late Asbian age (MFZ 14; late Viséan) (Krainer \& Vachard 2015). The bryozoan fauna that is described from these limestone clasts for the first time supports this age identification, displaying slightly wider distribution, which falls in the range of Asbian to Brigantian, reaching in the lowermost Serpukhovian.

The studied limestone block confirms the presence of a carbonate shelf and provides additional information on the depositional environments on the shelf. Coral bafflestone demonstrates that locally coral colonies formed small patch reefs (Rodríguez et al. 2018), and were associated with bryozoan bindstone.

The studied bryozoan association is represented by three encrusting species including one with complex honeycomb shaped colony consisting of numerous subcolonies (Glyptopora). All three species belong to the palaeostomate Order Cystoporata. Furthermore, fragments of unidentifiable trepostomes and fenestrates are present in the matrix pointing on moderate bryozoan diversity of the Kirchbach Formation. These species are represented by delicate branching colonies, with branch diameters less than $1 \mathrm{~mm}$. The combination of encrusting, sheetlike colonies and fenestrate-delicate branching colonies indicates high to moderate energy levels, moderate to high sedimentation rates and flexible to hard substrates (e.g. Amini et al. 2004). According to bryozoan growth forms, this environment can be classified as shallow shelf.

The identified bryozoan species, Fistulipora incrustans (Phillips, 1836), Eridopora macrostoma Ulrich, 1882, and Glyptopora michelinia (Prout, 1860), are typical for the Mississippian deposits in Europe. Fistulipora incrustans (Phillips, 1836) is known from the upper Viséan of Great Britain and Spain, whereas Eridopora macrostoma Ulrich, 1882 and Glyptopora michelinia (Prout, 1860) were recorded from the interval of the upper Viséan and lower Serpukhovian of North America and Europe.

\section{Conclusions}

Microfacies and fossil assemblage of the studied limestone block supports the idea that a shallow shelf was present along the northern margin of the Hochwipfel flysch basin (Flügel \& Schönlaub 1990, Amler et al. 1991, Krainer \& Vachard 2015, Vachard et al. 2018, Kabon \& Schönlaub 2019). Microfacies and fossil assemblages of the limestone block as well as the limestone clasts in the carbonate conglomerate of the Kirchbach Formation and the exotic limestone clasts of the Carboniferous of Nötsch are derived from this shallow shelf. The microfacies of the limestone block allow a more detailed characterization of the depositional environment of this shallow shelf. Coral bafflestone demonstrates that locally small patch reefs were present, associated with bryozoan bindstones. Patch reefs or skeletal mounds indicate formation during long periods of quiet water, periodically interrupted by short periods of higher water turbulence (Rodríguez et al. 2018). Microfacies of reworked limestone clasts are composed of wackestone, packstone, grainstone and rudstone containing a diverse fossil assemblage pointing deposition in a shallow, normal marine environment with moderate to high water energy (Flügel \& Schönlaub 1990, Amler et al. 1991, Krainer \& Vachard 2015). Limestone clasts composed of bindstone are derived from a very shallow, restricted shelf environment (Krainer \& Vachard 2015). The presence of encrusting, sheet-like bryozoan colonies associated with fenestrate, delicate-branching colonies indicates moderate to high water turbulence, moderate to high sedimentation rates and flexible to hard substrate on an open, shallow shelf above the wave base.

The assemblage of foraminifers and algae is more similar to the association recently found in exotic limestone clasts of the Carboniferous of Nötsch (Vachard et al. 2018) than to the association described from the Kirchbach Formation, which was dated as late Viséan MFZ 14 (Amler et al. 1991, Krainer \& Vachard 2015). Nevertheless, the Steshevian assemblage of the Carboniferous of Nötsch, reported by Vachard et al. (2018), shows more evolved taxa of foraminifers Miliolata and Endothyroidea. This indicates that the foraminiferal assemblage described in this paper is probably older, and Tarusian in age (i.e. earliest Serpukhovian and equivalent to the upper MFZ15 biozone).

Microfacies and fossil assemblage of the studied limestone block confirm that a shallow marine carbonate shelf was developed along the northern margin of the Hochwipfel flysch basin (see Vachard et al. 2018), from where clasts and larger blocks were transported into deeper marine environments by gravitational sedimentary processes. 


\section{Acknowledgements}

Andrej Ernst thanks Deutsche Forschungsgemeinschaft (DFG) for financial support (project ER 278/6.1). We greatly appreciate the comments and suggestions of Stanislava Vodrážková and Axel Munnecke which helped to improve the manuscript.

\section{References}

Amini, Z.Z., Adabi, M.H., Burrett, C.F. \& Quilty, P.G. 2004. Bryozoan distribution and growth form associations as a tool in environmental interpretation, Tasmania, Australia. Sedimentary Geology 167(1-2), 1-15. DOI 10.1016/j. sedgeo.2004.01.010

Amler, M.R.W., Conil, R. \& Kratz, K.R. 1991. Foraminifers from the Kirchbach Limestone (Carnic Alps, Austria). Geologica et Palaeontologica 25, 111-121.

Astrova, G.G. 1964. A new order of the Paleozoic Bryozoa. Paleontologicheskiy Zhurnal 1964(2), 22-31. [in Russian]

Bancroft, A.J. 1986. The Carboniferous cystoporate bryozoan Eridopora macrostoma Ulrich from the north of England. Proceedings of the Yorkshire Geological Society 46(1), 2328. DOI 10.1144/pygs.46.1.23

Bancroft, A.J. \& Wyse Jackson, P.N. 1995. Revision of the Carboniferous bryozoan Fistulipora incrustans (Phillips, 1836), with remarks on the type species of Fistulipora M'Coy, 1849. Geological Journal 30, 129-143.

DOI 10.1002/gj.3350300204

Bassler, R.S. 1953. Bryozoa, G1-G253. In Moore R.C. (ed.) Treatise on Invertebrate Paleontology Part G. xiii +253 pp. Geological Society of America, Boulder \& University of Kansas Press, Lawrence.

Borg, F. 1926. Studies on Recent cyclostomatous Bryozoa. Zoologiska Bidrag från Uppsala 10, 181-507.

Brady, H.B. 1873. On Archaediscus karreri, a new type of Carboniferous foraminifera. Annals and Magazine of Natural History 4(12), 286-290. DOI 10.1080/00222937308680769

Brady, H.B. 1876. A monograph of Carboniferous and Permian foraminifera (the genus Fusulina excepted). Palaeontographical Society of London 30, 1-166. DOI 10.5962/bhl.title.45546

Brazhnikova, N.E., Ichtchenko, A.M., Ichtchenko, T.A., NoviK, E.O. \& Shulga, P.L. 1956. Fauna and flora from Carboniferous deposits of the Galician-Volyn Basin. Trudy Instituta geologicheskikh nauk. Seria stratigrafii i paleontologii/ Akademia Nauk Ukrainkskoi SSR 10, 3-89. [in Russian]

CHINA, W.E. 1965. Opinion 724. Endothyra bowmani Phillips (1846) (Foraminifera): validated under the plenary powers. Bulletin of Zoological Nomenclature 22, 37-39.

Crockford, J. 1947. Bryozoa from the Lower Carboniferous of New South Wales and Queensland. Proceedings of the New South Wales Linnean Society 72, 1-48.

Ehrenberg, C.G. 1831. Symbolae Physicae, seu Icones et descptiones Corporum Naturalium novorum aut minus cognitorum, quae ex itineribus per Libyam, Aegiptum, Nubiam, Dongalaam, Syriam, Arabiam et Habessiniam, studia annis 1820-25, redirent. Pars Zoologica, 4, Animalia Evertebrata exclusis Insectis. 10 pls. Berolini.

Ehrenberg, C.G. 1854. Zur Mikrogeologie. 374 pp. Verlag von Leopold Voss, Leipzig.

ERnst, A. \& Rodríguez, S. 2013. Stenolaemate bryozoan fauna from the Mississippian of Guadiato Area, southwestern Spain. Spanish Journal of Palaeontology 28(2), 173-192. DOI 10.7203/sjp.28.2.17851

ERnst, A. \& VAChard, D. 2017. The cystoporate bryozoan Glyptopora michelinia (Prout, 1860) in the ViséanSerpukhovian boundary interval of the Montagne Noire (southern France). Paläontologische Zeitschrift 91, 207-216. DOI 10.1007/s12542-017-0336-x

Flügel, E. \& Schönlaub, H.P. 1990. Exotic limestone clasts in the Carboniferous of the Carnic Alps and Nötsch, 15-19. In Venturini, C. \& Krainer, K. (eds) Proceedings of field workshop on Carboniferous to Permian sequence of the Pramollo-Nassfeld Basin (Carnic Alps). Arti Grafiche Friulane, Udine.

GorJunova, R.V. 1988. Novyye kamennougol'nyye mshanki Gobiyskogo Altaya, 10-23. In Rozanov A.Y. (ed.) Novyye iskopayemyye bespozvonochnyye Mongolii. Trudy Sovmestnoi Sovetsko-Mongol'skoi Paleontologicheskoi Ekspeditsii 33.

Grozdilova, L.P. 1953. Iskopaemye foraminiferi SSSR: Arkhedistsidy. Trudy VNIGRI 74, 67-123. [in Russian; French translation, M. Jayet, BRGM, 1816: 1-124]

Hall, J. 1883. Bryozoans of the Upper Heidelberg and Hamilton groups. Transactions of the Albany Institute 10, 145-197.

IvANOVA, R.M. 1973. K stratigrafii sredne- i verkhnevizeiskikh otlozhenii vostochnogo sklona Yuzhnogo Urala, 18-86. In Malakhova, N.P. \& Chuvashov, B.I. (eds) Kamennougolnye otlozheniya vostochnogo sklona Yuzhnogo Urala (Early Carboniferous from the eastern slope of the southern Urals). Akademiya Nauk SSSR, Ural Nauchnyi Tsentr, Trudy Instituta Geologii i Geokhimii 82. [in Russian]

KabOn, H. \& SchÖNlaub, H.P. 2019. Das geologische Geheimnis der Hochwipfel Formation der Karnischen Alpen (Österreich) Italien). 162 pp. Verlag des Naturwissenschaftlichen Vereins für Kärnten, Klagenfurt am Wörthersee.

KonisHI, K. 1956. Anatolipora, a new Dasycladacean genus, and its algal associates from the Lower Carboniferous of Japan, 109-127. In Johnson, J.H. \& Konishi, K. (eds) Studies of Mississippian algae. Quarterly of the Colorado School of Mines 51.

Krainer, K. \& Vachard, D. 2015. Late Viséan (MFZ 14) foraminifers and algae from the Kirchbach Limestone (Carnic Alps, Austria) and geological implications. Facies 61, 418 (2015). DOI 10.1007/s10347-014-0418-0

Kulagina, E.I., Rumyantseva, Z.C., Pazukhin, V.N. \& KocheTOVA, N.N. 1992. Granitsa nizhnego-srednego karbona na yuzhnom Urale i srednem Tyan-Shane. Rossiiskaya Akademiya Nauk, Uralskoe Otdelenie, Bashkirskii Nauchnyi Tsentr, Institut Geologii, Moskva, Nauka, 1-112. [in Russian]

MA, J.-Y., Buttler, C.J. \& TAYLOR, P.D. 2014. Cladistic analysis of the 'trepostome' Suborder Esthonioporina and the systematics of Palaeozoic bryozoans, 153-161. In Rosso, A., 
Wyse Jackson, P.N. \& Porter, JS. (eds) Bryozoan Studies 2013. Museo delle Scienze, Trento.

M'Coy, F. 1849. On some new genera and species of Palaeozoic Corals and Foraminifera. Annals and Magazine of Natural history 3(2), 119-136.

DOI 10.1080/03745485909494606

McKinney, F.K. 1972. Nonfenestrate Ectoprocta (Bryozoa) of the Bangor Limestone (Chester) of Alabama. Geological Survey of Alabama Bulletin 98, 1-144.

Meek, F.B. \& Worthen, A.H. 1865. Notice on some new types of organic remains from the Coal Measures of Illinois. Proceedings of the Academy of Natural Sciences of Philadelphia 18, 46-51.

Morozova, I.P. 1970. Late Permian Bryozoa. Trudy Paleontologicheskogo Instituta Akademii Nauk SSSR 122, 1-347. [in Russian]

Morozova, I.P., Weis, O.B. \& Racki, G. 2006. New Devonian and Carboniferous bryozoans of the Holy Cross Mountains (Central Poland). Paleontological Journal 40(5), 529-540. DOI 10.1134/S0031030106050078

NeKhoroshev, V.P. 1953. Nizhnekamennougol'nye mshanki Kazakhstana. Trudy Vsesoyuznogo Nauchno-Issledovatelskogo Instituta (VSEGEI), 1-183. [in Russian]

Perry, T.G. \& Horowitz, A.S. 1963. Bryozoans from the Glen Dean Limestone (Middle Chester) of southern Indiana and Kentucky. Indiana Geological Survey Bulletin 26, 1-51.

Phillips, J. 1836. Illustrations of the geology of Yorkshire. Pt. 2. The Mountain Limestone District. 253 pp. John Murray, London.

Phillips, J. 1846. On the remains of microscopic animals in the rocks of Yorkshire. Proceedings of the Geological and Polytechnic Society of the West Riding of Yorkshire (1844-1845) 2, 274-285. DOI 10.1144/pygs.2.274

Poty, E., Devuyst, F.X. \& Hance, L. 2006. Upper Devonian and Mississippian foraminiferal and rugose coral zonations of Belgium and Northern France, a tool for Eurasian correlations. Geological Magazine 143, 829-857.

DOI 10.1017/S0016756806002457

Prout, H.A. 1860. Fourth series of descriptions of Bryozoa from the Paleozoic rocks of western states and territories. Transactions of St. Louis Academy of Sciences, series 3, 571-581.

Prout, H.A. 1866. Descriptions of Polyzoa from the Paleozoic rocks. Illinois State Geological Survey 2, 412-423.

Rauzer-Chernousova, D.M. 1948a. Nekotorye novye nizhnekamennougolnye foraminifery Syzranskogo raiona. Akademiya Nauk SSSR, Trudy Instituta Geologicheskikh Nauk 62, geologicheskaya seriya 19, 239-243. [in Russian]

Rauzer-Chernousova, D.M. 1948b. Materialy k faune foraminifer kamennougolnykh otlozhenii Tsentralnogo Kazakhstana (Data on the fauna of foraminifers of the Carboniferous deposits of the Central Kazakhstan). Akademiya Nauk SSSR, Trudy Instituta Geologicheskikh Nauk, 66, geologicheskaya seriya 21, 1-66 [in Russian].

Reitlinger, E.A. 1956. Novoe semeistvo Lasiodiscidae (New family Lasiodiscidae). Voprosy Mikropaleontologii 1, 69-78. [in Russian; French translation, Sigal, S. \& Sigal, J., BRGM $n^{\circ}$ 1753: 1-16]

Rich, M. 1980. Carboniferous calcareous Foraminifera from Northeastern Alabama, South-Central Tennessee, and Northwestern Georgia. Cushman Foundation for Foraminiferal Research, special publication 18, 1-62.

Rodríguez, S., Schönlaub, H.P. \& Kabon, H. 2018. Lonsdaleia carnica n. sp., a new colonial coral from the late Mississippian Kirchbach Formation of the Carnic Alps. Jahrbuch der Geologischen Bundesanstalt 158, 49-57.

Schönlaub, H.P. 1985. Das Paläozoikum der Karnischen Alpen, 34-52. In SchÖNLAuB, H.P. (ed.) Arbeitstagung der Geologischen Bundesanstalt 195. Kötschach-Mauthen, Gailtal.

Schönlaub, H.P., Spalletta, C. \& Venturini, C. 2015. Kirchbach Formation, 148-150. In Corradini, C. \& SutTNER, T.J. (eds) The Pre-Variscan Sequence of the Carnic Alps (Austria and Italy). Abhandlungen der Geologischen Bundesanstalt 69.

Schulga-Nesterenko, M.I. 1955. Carboniferous Bryozoa from the Russian Platform. Trudy Paleontologischeskogo Instituta Akademiya Nauk SSSR 58, 1-207. [in Russian]

ShLYKova, T.I. 1951. Foraminifery vizeiskogo i namurskogo yarusov nizhnego karbona zapadnogo kryla Podmoskovnoi kotloviny. Trudy VNIGRI 56, 109-178. [in Russian]

Simpson, G.B. 1895. A handbook of the genera of the North American Paleozoic Bryozoa. Annual Report of the State Geologist (of New York) for the Year 1894 14, 407-608.

Ulrich, E.O. 1882. American Palaeozoic Bryozoa. The Journal of the Cincinnati Society of Natural History 5, 121-175, 233-257.

Ulrich, E.O. 1884. American Palaeozoic Bryozoa. The Journal of the Cincinnati Society of Natural History 8, 24-51.

Ulrich, E.O. 1890. Part II. Palaeontology of Illinois. Section VI. Palaeozoic Bryozoa. Report of the Geological Survey of Illinois 8, 283-688.

UtgaARd, J. 1983. Systematic descriptions for the Order Cystoporata, 358-439. In RoBIson, R.A. (ed.) Treatise on Invertebrate Paleontology, Part G, Revised, Bryozoa. Geological Society of America and University of Kansas Press, Boulder, Colorado \& Lawrence, Kansas.

Vachard, D., Krainer, K. \& Schönlaub, H.P. 2018. Lower Serpukhovian (Steshevian) foraminifers and algae from exotic limestone clasts of the Carboniferous of Nötsch (Eastern Alps, Austria). Geobios 51, 75-100.

DOI 10.1016/j.geobios.2017.12.005

VISSARIONOVA, A.Y. 1948. Nekotorye vidy podsemeitsva Tetrataxinae Galloway iz vizeiskogo yarusa evropeiskoi chasti Soyuza. Akademiya Nauk SSSR, Trudy Instituta Geologicheskikh Nauk, 62, geologicheskaya seriya 19, 190-195. [in Russian]

WaAgen, W. \& Wentzel, J. 1886. Salt Range Fossils. ProductusLimestone Fossils: Coelenterata. Memoirs of the Geological Survey of India, Paleontologica Indica, Series 13(1), 835-924. 